\title{
EVALUASI PERKANDANGAN KAMBING PERAH LAKTASI DI PETERNAKAN ALAM FARM MANGLAYANG KECAMATAN CILENGKRANG KABUPATEN BANDUNG
}

\author{
(EVALUATION OF HOUSING DAIRY GOATS LACTATION AT ALAM RANCH \\ MANGLAYANG FARM, CILENGKRANG DISTRICT, BANDUNG REGENCY)
}

\author{
RADEN FEBRIANTO CHRISTI ${ }^{1}$, LIA BUDIMULYATI SALMAN ${ }^{1}$, HERMAWAN1, AJAT SUDRAJAT ${ }^{2}$ \\ ${ }^{1}$ Laboratorium Produksi Ternak Perah Departemen Produksi Ternak Fakultas Peternakan Universitas Padjadjaran Sumedang \\ ${ }^{2}$ Departemen Teknologi Peternakan Fakultas Agroindustri Universitas Mercubuana Yogyakarta \\ Korespondensi Email : raden.febrianto@unpad.ac.id
}

\begin{abstract}
The house is a place to live for animals that can provide a sense of comfort free from outside disturbances. A good house has the right size as well as the parts in the house such as ventilation. If the house is not in accordance with the needs of the livestock itself, it can cause stress so that it will have an impact on the performance of milk production. The aim of the study was to evaluate the sizes of the house for lactating dairy goats which included length, width, height and height from the ground surface. The research activity was carried out at the Alam Manglayang Dairy Goat Farm, Cilengkrang District, Bandung Regency, West Java. This research uses quantitative descriptive analysis . Sample data were obtained from 30 dairy goat house that were lactating. The results showed that the size of the dairy goat house at Alam Dairy Goat Farm produced an average of $140.4 \times 102 \times 181.5 \mathrm{~cm}$ in each large house (A), $121.6 \times 105.5 \times 170 \mathrm{~cm}$ house (B). $142 \times 101 \times 175 \mathrm{~cm}$ (House C), 122x100x170 cm (House D) with an average height of the house from the ground surface $73-81 \mathrm{~cm}$ so that the coefficient of variation ranges from 0.000174-0.000467 and is still in normal condition. The conclusion shows that the house for lactating dairy goats in Alam Farm Manglayang's dairy goat farm are still in relatively normal condition and other house requirements meet the standards.
\end{abstract}

Keywords: management, housing, dairy goats, alam farm manglayang

\section{ABSTRAK}

Kandang merupakan tempat tinggal untuk hewan yang dapat memberikan rasa nyaman bebas dari gangguan luar. Kandang yang baik memiliki ukuran yang sesuai serta bagian-bagian dalam kandang seperti ventilasi. Apabila kandang tidak sesuai dengan kebutuhan dari ternak itu sendiri maka dapat menyebabkan stress sehingga akan berdampak kepada performa produksi susunya. Penelitian bertujuan untuk mengevaluasi ukuran-ukuran kandang kambing perah laktasi yang meliputi panjang, lebar, tinggi serta tinggi dari permukaan tanah. Kegiatan penelitian dilakukan di Peternakan Kambing Perah Alam Farm Manglayang Kecamatan Cilengkrang Kabupaten Bandung Jawa Barat. Penelitian menggunakan analisis deskriptif kuantitatif . Data sampel diperoleh dari 30 kandang kambing perah yang sedang laktasi. Hasil penelitian menunjukkan bahwa ukuran kandang kambing perah di Peternakan Kambing Perah Alam Farm menghasilkan rata-rata pada setiap kandang besar (A) 140,4 x 102 x181,5 cm, kandang (B) 121,6 x 105,5 x $170 \mathrm{~cm}$, Kandang (C) $142 \times 101 \times 175 \mathrm{~cm}$, Kandang D 122x100x170 cm dengan rataan tinggi kandang dari permukaan tanah 73-81 cm sehingga koefisien variasi berkisar antara 0,000174-0,000467 dan masih dalam keadaan normal. Kesimpulan menunjukkan bahwa perkandangan kambing perah laktasi yang terdapat di Peternakan kambing perah Alam Farm Manglayang masih dalam kondisi yang relatif normal dan persyaratan kandang lainnya memenuhi standar.

Kata kunci : manajemen, perkandangan, kambing perah, alam farm manglayang

\section{PENDAHULUAN}

Kambing perah merupakan salah satu jenis ternak yang memiliki manfaat untuk diambil susunya. Namun kebanyakan jenis kambing perah yang terdapat di masyarakat memiliki dwifungsi yaitu sebagai penghasil daging dan susu. Susu 
kambing perah sebenarnya masih belum begitu familiar di masyarakat tetapi satu sisi yang lain bahwa hasil protein hewani tersebut memiliki banyak khasiat sebagai obat dikalangan masyarakat luas sehingga permintaan meningkat harga pun sangat mahal bila dibandingkan dengan harga susu sapi. Sehingga sekarang ini banyak masyarakat yang menginginkan untuk beternak kambing perah. Banyak sekali berbagai jenis kambing perah yang dipelihara seperti Peranakan etawa, alpin, saanen, jawa randu dan sapera.

Kambing sapera merupakan hasil persilangan antara kambing saanen jantan dan kambing PE betina. Kambing jenis ini merupakan kambing tipe perah sebagai penghasil susu. Kambing jenis tersebut cukup memberikan performa hidup yang baik diantaranya dapat bertahan pada wilayah atau kondisi yang sedang tanpa harus hidup pada kondisi yang normalnya . Karakteristik dari kambing sapera adalah warna putih atau krem polos, muka datar, telinga sedang dan tanduk kecil. Tinggi badannya bisa mencapai lebih dari $70 \mathrm{~cm}$, kolostrum dengan kadar lemak rata-rata 9\% (Christi dkk., 2021) dan produksi susu yang relatif tinggi 1,5-2 liter.

Salah satu faktor utama dalam manajemen pemeliharaan kambing perah adalah perkandangan.

Adanya kandang yang berfungsi untuk melindungi kambing khususnya dalam hal ini kambing perah yang sedang laktasi (Hamdan et al., 2018). Peternak belum memahami secara tepat dalam membangun kandang, ukuran kandang serta tata letak kandang yang tepat. Hal tersebut dapat mengganggu performa produksi kambing perah yang sedang tinggi. Pendirian kandang bertujuan untuk melindungi dari pengaruh iklim baik panas, hujan, angin dan suhu atau temperatur dan juga untuk melindungi dari serangan hewan liar atau pencurian ternak kambing. Persyaratan kandang kambing perah yang baik adalah jauh dari pemukiman, bersih, memiliki sinar matahari yang cukup (ventilasi), dan tidak panas (Mabjesh et al., 2013).

Tujuan kandang harus jauh dari area pemukiman adalah menghindari bau kotoran bercampur urine yang dapat mempengaruhi kesehatan ternak, peternak dan masyarakat disekitarnya. Sesuai Peraturan Menteri No 102/Permentan/OT.140/7/2014 tentang
Pedoman Pembibitan Kambing dan Domba, luasan kandang untuk induk laktasi 0,7 - 1 $\mathrm{m}^{2}$ /ekor ditambah 0,5 m2/ekor. Menurut Syukur (2016) ukuran kandang kambing adalah Ukuran kandang yang biasa digunakan yaitu kandang kambing beranak $120 \mathrm{~cm} \times 120 \mathrm{~cm}$ /ekor, kandang kambing Induk $100 \mathrm{~cm}$ x $125 \mathrm{~cm}$ / ekor, kandang kambing anak $100 \mathrm{~cm}$ x $125 \mathrm{~cm}$ / ekor, kandang kambing pejantan $110 \mathrm{~cm} \mathrm{x} 125$ $\mathrm{cm} /$ ekor, dan kandang kambing dewasa $100 \mathrm{~cm}$ x $125 \mathrm{~cm} /$ ekor. Guntur (2019) melaporkan ukuran kandang kambing kacang betina dan jantan ditingkat peternak adalah $150 \times 150 \mathrm{~cm}$. Kondisi yang demikian sangat penting untuk melakukan evaluasi perkandangan kambing perah di Peternakan Alam Farm Manglayang guna untuk peningkatan produktivitasnya.

\section{MATERI DAN METODE Tempat Penelitian}

Kegiatan penelitian ini telah dilaksanakan pada november 2021 di Peternakan Kambing Perah Alam Farm Manglayang Kecamatan Cilengkrang Kabupaten Bandung.

\section{Materi Penelitian}

Objek penelitian adalah 4 Kandang kambing perah besar yang sedang laktasi. Pada setiap kandang besar terdapat masing-masing 5 kandang koloni sehingga total keseluruhan kandang sebanyak 20 kandang laktasi. Data primer ukuran kandang diperoleh langsung dengan mengukur panjang, lingkar, tinggi kandang serta tinggi kandang dari permukaan tanah. Metode purposive sampling cara yang dilakukan dalam pengambilan data tersebut.

\section{Analisis Statistik}

Analisis statistik menggunakan analisis deskriptif dengan menghitung rata-rata, standar deviasi, dan koefisien variasi. Rumus analisis statistika deskriptif adalah sebagai berikut:

1. Rata-rata:

$-\quad=\frac{\sum x i}{n}$

Keterangan:

- $\quad=$ Rata-rata

$\sum x i=$ Jumlah seluruh data

$\mathrm{n} \quad=$ Banyaknya data 
2. Simpangan baku adalah akar dari ragam. Ragam merupakan jumlah kuadrat semua deviasi nilai-nilai individu terhadap rata-rata populasi dengan rumus sebagai berikut:

$s=\frac{\sum \sqrt{\left(\mathrm{xi}^{-}\right)^{2}}}{\mathrm{n}-1}$

Keterangan :

$\mathrm{s}$ = Simpangan baku

$\mathrm{xi}=$ Nilai data ke-i

- $=$ Rata-rata

$\mathrm{n}$ = Banyaknya data

5. Koefisien variasi merupakan ukuran yang digunakan untuk mengetahui besarnya variasi nilai dari hasil pengukuran variabel yang diamati dengan menggunakan rumus:

$\mathrm{KV}=\frac{s}{x} \times 100 \%$

Keterangan:

$\mathrm{KV}=$ Koefisien variasi

$$
\begin{aligned}
& \mathrm{S}=\text { Simpangan baku } \\
& \mathrm{x}=\text { Rata-rata }
\end{aligned}
$$

\section{HASIL DAN PEMBAHASAN}

Tolak ukur keberhasilan di dalam manajemen usaha peternakan kambing perah adalah pemeliharaan kandang (Sitepu dan Marisa, 2020). Kandang yang baik tentu akan memberikan dampak yang positif bagi ternak kambing perah apabila terjadi sebaliknya kandang dengan kondisi yang buruk maka akan memberikan dampak negatif yaitu menurunya performa produksi susu. Kandang kambing perah harus memiliki luasan yang ideal, ventilasi cukup, serta yang paling penting adalah kebersihan. Berikut ini adalah Hasil pengamatan terhadap ukuran kandang kambing perah laktasi terdapat pada Tabel 1.

Tabel 1. Tampilan Ukuran pada setiap kandang laktasi (luasan sama)

\begin{tabular}{lcccc}
\hline Ukuran Kandang & Kandang A & Kandang B & Kandang C & Kandang D \\
\hline $\begin{array}{l}\text { Rataan Panjang kandang } \\
\text { (cm) }\end{array}$ & 140,4 & 121,6 & 142 & 122 \\
$\begin{array}{l}\text { Rataan Lebar kandang (cm) } \\
\text { Rataan Tinggi kandang }\end{array}$ & 102 & 105,5 & 101 & 100 \\
$\begin{array}{l}\text { dalam (cm) } \\
\text { Rataan Tinggi kandang dari }\end{array}$ & 181,5 & 170 & 175 & 170 \\
permukaan tanah (cm) & 81 & 80 & 76 & 73 \\
SB & 2,14 & 1,81 & 5,24 & 5,70 \\
KV & 0,000174 & 0,000149 & 0,000369 & 0,000467
\end{tabular}

Keterangan : SB : Simpangan Baku, KV: Koefisien Variasi

Berdasarkan Tabel 1 hasil penelitian menunjukkan bahwa rataan ukuran kandang di Peternakan Kambing Perah Alam Farm Manglayang adalah pada kandang A (140,4 x $102 \mathrm{x} 181,5 \mathrm{~cm})$ sedangkan tinggi dari permukaan tanah $81 \mathrm{~cm}$, kandang B ( $121,6 \mathrm{x}$ $105,5 \times 170 \mathrm{~cm}$ ) tinggi dari permukaan tanah 80 $\mathrm{cm}$, kandang $\mathrm{C}(142 \times 101 \times 175 \mathrm{~cm})$ tinggi dari permukaan tanah $76 \mathrm{~cm}$, kandang D $(122 \times 100 \times 170 \mathrm{~cm})$ tinggi dari permukaan tanah $73 \mathrm{~cm}$. Kondisi demikian menyebabkan kisaran rataan nilai ukuran sedikit berbeda tetapi masih dalam relatif normal. Sedangkan koefisien variasi juga masih dalam kisaran normal $(<10 \%)$.
Menurut Verwandi (2021) mengatakan bahwa ukuran kandang kambing perah yang sedang laktasi memiliki ukuran panjang $150 \mathrm{~cm}$, lebar $120 \mathrm{~cm}$, tinggi $70 \mathrm{~cm}$. Menurut Kementrian pertanian (2014) induk kambing yang sedang laktasi memiliki luasan kurang lebih $1 \mathrm{~m}^{2}$ dengan ukuran kandang panjang dan lebar adalah $170 \times 140 \mathrm{~cm}$. Berdasarkan tipe kandang pada kambing maka kandang terbagi menjadi dua bagian yaitu kandang panggung dan non panggung. Kandang panggung banyak diminati oleh para peternak. Hal ini karena kandang tersebut mudah dalam proses penanganan salah satunya adalah dalam melakukan kebersihan. 
Keunggulan lain dari kandang panggung adalah mencegah pakan tercampur dengan kotoran, sekaligus memudahkan saat memberi pakan dan bersamaan dengan pembersihan kandang dari sisa pakan dan kotoran. Hal ini dilaporkan oleh Nagy dan Pugh (2012) bahwa kandang berguna untuk melindungi ternak dari lingkungan ekstrim, meningkatkan kenyaman guna untuk menghasil performa reproduksi dan produksi yang baik, serta memudahkan penanganan dalam hal manajemen pemeliharaan.

Jenis kandang kambing perah yang terdapat dilokasi penelitian adalah kandang panggung dengan lantai kayu atapnya berbentuk shape terbuat dari asbes (atapnya membentuk setengah segitiga,), dinding setengah terbuka bagian atas sekaligus membantu sirkulasi udara. Selain itu, hal yang penting dalam kandang yaitu atap dibuat kemiringan 30 derajat yang berguna untuk menghindarkan ternak dari air hujan dan terik matahari serta menjaga kehangatan pada malam hari (Koluman dan Daskiran, 2011).

Lantai kandang terbuat dari kayu yang bercelah berfungsi menahan teracak kaki kambing namun kotoran dapat turun ke bawah. Jarak tinggi dari permukaan tanah $70-80 \mathrm{~cm}$ sehingga suhu kandang tidak mudah panas. Pada siang hari terjadi peningkatan suhu yang cukup tinggi dan dapat menggangu performa produksi kambing perah. Seixas et al (2017) melaporkan bahwa kondisi lingkungan panas menyebabkan mekanisme termoregulasi akan aktif untuk mengeluarkan panas agar suhu tubuh tetap normal. Hal tersebut melibatkan kerja sistem respirasi, sirkulasi, ekskresi, endokrin, dan syaraf. Kondisi demikian, kandang yang dibuat dalam area peternakan perlu diperhatikan terutama ukuran-ukurannya agar dihasilkan performa baik.

Kandang sebaiknya dibuat miring kurang lebih 7 derajat untuk memudahkan aliran urin dan pembersihan feses, saluran feses sebaiknya dibuat tertutup karena dekat dengan perumahan penduduk, atap kandang direkomendasikan terbuat dari asbes atau bahan lain yang meredam panas karena perubahan suhu yang esktrim akan berdampak secara fisiologis (Badriyah et al. 2018). Ukuran ketinggian di dalam kandang sangat berpengaruh pula terhadap kemampuan ternak kambing perah dalam mentolerasi suhu tubuhnya untuk menyesuaikan dengan lingkungan (Thakare et al., 2017).

Peternakan Kambing Perah Alam Farm Manglayang termasuk salah peternakan kambing perah yang cukup baik mulai dari pendirian kandang. Bentuk usaha peternakan tersebut sudah mulai memperhatikan hukum untuk kebaikan usahanya. Oleh karena itu, dengan melakukan kajian evaluasi terhadap kandang kambing perah laktasi maka diharapkan jika tidak sesuai dengan aturan yang berlaku setidaknya dapat dirubah menjadi lebih baik agar dapat menghasilkan performa produksi yang tinggi sehingga sesuai dengan harapan yang diinginkan guna keberlangsungan di dalam manajemen pemeliharaanya.

\section{KESIMPULAN}

Perkandangan di peternakan kambing perah Alam Farm Manglayang masih dalam kondisi yang relatif normal hal ini diketahui dari ukuran-ukuran panjang, lebar, tinggi kandang serta ketinggian dari dasar atau permukaan kandang dan persyaratan kandang lainnya sudah memenuhi standar dengan baik

\section{UCAPAN TERIMAKASIH}

Ucapan terimakasih kepada seluruh tim peneliti yang telah membantu dengan baik pada kegiatan penelitian ini. Tidak lupa ucapkan kepada mahasiswa yang terlibat dalam penelitian ini sudah membantu teknis di lapangan. Kami juga ucapkan terimakasih yang sebesar-besarnya kepada Bapak Heru selaku bagian dari pemilik peternakan kambing perah Alam Farm Manglayang sebagai mitra kerjasama yang telah memberikan sarana penelitian guna untuk mendapatkan hasil dan sebagai referensi untuk perbaikan manajemen pemeliharaan khususnya perkandangan.

\section{DAFTAR PUSTAKA}

BADRIYAH A, SISWANTO, ERWANTO, QISTHON A. 2018. Pengaruh Manipulasi Suhu Kandang terhadap Kadar Glukosa dan Urea dalam Darah Pada Kambing Boer Dan Peranakan Ettawa (PE). Jurnal Riset dan Inovasi Peternakan. 3 (2) : 3944.

CHRISTI, R.F., D. SUHARWANTO., DAN E. YUNIARTI. 2021. Karakteristik 
Kandungan Kimia Kolostrum Kambing Sapera dan Saanen Di Sumedang Jawa Barat. Jurnal Ilmu Pertanian dan Peternakan 9 (1) : 96-101 Fakultas Pertanian Universitas Majalengka.

GUNTUR, M.,A. TOHARDI., DAN Y.ROHAYETI. 2000. Morfometri Kambing Kacang (Capra aegagrus) Di Desa Rasau Jaya III Kecamatan Rasau Jaya Kabupaten Kubu Raya Provinsi Kalimantan Barat. Fakultas Pertanian Universitas Tanjungpura Pontianak Kalimantan Barat.

HAMDAN, A., B.P. PURWANTO, D.A. ASTUTI, A. ATABANY, DAN E. TAUFIK. 2018. Respons kinerja produksi dan fisiologis kambing peranakan ettawa terhadap pemberian pakan tambahan dedak halus pada agroekosistem lahan kering di Kalimantan Selatan. Pengkajian dan Pengembangan Teknologi Pertanian 12(1) : 73--84

KEMENTERIAN PERTANIAN. 2014. Lampiran Peraturan Menteri Pertanian Republik Indonesia Nomor: 64/Permentan/OT.140/5/2014 tentang Pedoman Budidaya Kambing Perah yang Baik.

KOLUMAN, N AND I. DASKIRAN. 2011. Effects of ventilation of the sheep house on heat stress,growth and thyroid hormones of lambs. Journal Tropical Animal Health Production 43:1123--1127.

MABJEESH, S.J., C. SABASTIAN, O. GALGARBER, DAN A. SHAMAY. 2013. Effect of photoperiod and heat stress in the third trimester of gestation on milk production and circulating hormones in dairy goats. Journal Of Dairy Science. 96 : 189-197.

NAGY DW, PUGH DG. 2012. Handling and Examining Sheep and Goats. Second Edition. Edited by DG Pugh and AN Baird. Missouri (US): Saunders, an imprint of Elsevier Inc.

SEIXAS, L., C.B. DE MELO, C.B. TANURE, V. PERIPOLLI, AND C. MC.MANUS. 2017. Heat tolerance in Brazilian hair sheep. AsianAustralasian J. Anim. Sci. 30(4): 593-601.
SITEPU, S.A DAN J. MARISA. 2020. Manajemen Usaha Ternak Perah Kambing Peranakan Etawa. Penerbit Mitra Cendekia Media Solok Sumatera Barat.

THAKARE, P.D., A.R. SIROTHIA, AND A.R. SAWARKAR. 2017. Heat tolerance ability and its variability in different breeds of goat with reference to pulse rate. Int. J. Current Innovation Research 3(9): 805-806.

VERWANDY. 2020. Ukuran Kandang Kambing yang Ideal. Laporan Penyuluh Pertanian Muda pada Disbunnak Prov. Sulteng. 